\title{
Essence of Technology and Ecological Disaster: A Heideggerian Reading of Margaret Atwood's The Year of the Flood
}

\author{
WU LANXIANG \\ ZHOU XIAOLIN
}

\begin{abstract}
In his criticism about modern technology, Martin Heidegger etymologically examines the word "Technē" and points out that, technology, as a mode of revealing, does not solely refer to the bringing forth of truth through machine-based experiments and exploration, it also contains the poetic revealing inside which a saving power can be found. Following this argument, this paper conducts a textual analysis of Margaret Atwood's 2009 novel The Year of the Flood and argues that the Compound elites are so delivered over to technology that they have turned everything into standing-reserve, and thereby have fueled the impending ecological disaster in their pursuit of bioengineering innovation. By contrast, a Heideggerian meditative person - Adam One, the leader of God's Gardeners, illustrates the practice of "arts of the mind" by his words and his deeds, exemplifying the possibility of poetic revealing in an emblematic way. Although the trajectory of environmental deterioration cannot be reversed, the ending of the novel does strike a promising note by referring to music, an old form of fine arts.
\end{abstract}

Keywords: Margaret Atwood; The Year of the Flood; Martin Heidegger; technology

In her book review of Canadian writer Margaret Atwood's 2003 novel Oryx and Crake, Joyce Carol Oates (2006) is impressed by this "more ambitious and darkly prophetic work." The second book in Atwood's dystopia trilogy, The Year of the Flood (2009), is equally predictive. Through two key characters Toby (changed to Tobitha later in the novel) and Ren (also known as Brenda), a dystopian world unfolds where technology has pushed human beings onto the road of extermination, and an eco-religious rooftop community offers a fragile hope for the possible way out of the apocalyptic trap.

The specter of destructive force has drawn the attention of several reviewers who have done research about this book. While Gerry Canavan "follows Jameson's historical imperative" to "draw out the unexpected utopian potency 
Essence of Technology and Ecological Disaster

lurking within our contemporary visions of eco-apocalypse” (2012: 139), Hannes Bergthaller centers around the term of "anthropotechnologies" and traces the roots of ecological crisis to the failure of imagination. He believes that human imagination as the home turf shoulders the role of understanding and overcoming the crisis (2010: 730). J. Brooks Bouson also examines the cause of environmental destruction by evoking the threat of corporate/business cannibalism (2011: 12). Defining the novel as "a feminist, anti-corporate and radically ecological work" (2011: 23), she not only explores how male commodification has turned vulnerable women into sexual prey of men, but also affirms that Atwood looks to eco-religion "to find a remedy to humanity's ills." (2011: 9)

Similar to these critics who are enthralled by Atwood's environmental and technological imagination, we will address this issue by researching the driving force behind the formation of this catastrophic world and illuminate how an open space can be created out of this bleak vision of the world. To do this, we will explore Martin Heidegger's conception of the essence of technology before we analyze the technological practice of the Compound, a ruling corporation in the novel, and address how Adam One, the leader of the God's Gardeners, seeks to foster the growth of saving power in "poetic revealing" and attempts to bring the world back to its proper order.

\section{Technology as a Revelation}

In the beginning of his essay "The Question Concerning Technology," Martin Heidegger affirmatively states that " $\mathrm{t}]$ echnology is not equivalent to the essence of technology." (Heidegger 1977: 4) That fact that we regard technology as something neutral makes us blind to the essence of technology. Technology is, to quote William Lovitt, "a human construction," manifesting "the way in which modern man as subject represents reality." (Lovitt 1977: xxvi) Driven by the increasing drive to objectify the world, to master whatever confronts him, modern man goes further away from the "vital awareness of the real." (Lovitt 1977: xxvii)

In his effort to clarify the concept of technology, Heidegger, in his essay, traces the word back to its Greek origin. As he has found out, this word stems from a Greek word "Technikon" which "means that which belongs to Technē" (1977: 12). The word techne, unlike the taken-for-granted interpretation in our assumption, exhibits two layers of meanings: "One is that Technē is the name not only for the activities and skills of the craftsman, but also for the arts of the mind and the fine arts. Technē belongs to bringing-forth, to poiēsis that is 
poetic." (1977: 13) The other layer, as explained by Heidegger, is closely related to the word epistēme, both of which "mean to be entirely at home in something, to understand and be expert in it." (ibid.) The capability of knowing brings forth a revelation, helping to uncover "whatever does not bring itself forth and does not yet lie here before us, whatever can look and turn out now one way and now another." (ibid.) As these two layers of meaning indicate, "technology is a mode of revealing" (ibid.). But unfortunately, modern man has turned modern technology into a mere example about the natural world that presumably awaits to serve mankind, neglecting the truth about the world in a real sense.

By questioning the essence of technology (both in ancient and modern senses), Heidegger criticizes modern man's arrogance toward nature and their unawareness of the danger that puts nature as a standing-reserve, a status or condition where "[e]verywhere everything is ordered to stand by, to be immediately at hand, indeed to stand there just so that it may be on call for a further ordering." (1977: 17) Different from technology in its original sense, modern technology focuses primarily on experiments that require precise data or sophisticated calculations. On one hand, there is technological progress for humankind, testified by richer varieties of products and more comfortable modes of living; on the other hand, human beings' limited vision enslaves themselves in the prison of modern technology, for they tend to equate what is usable with what is true.

But, as Heiddeger suggests in the second half of his essay, there is a saving power in the very place where the danger grows. To find the way out of the trap of what Heidegger calls the challenging revelation of modern technology, one needs to go back to the origin of the word Technē, to remind oneself that, one layer of the meaning has been overemphasized and the other layer ignored, that is, Technē does not solely refer to the bringing forth of the truth about this world through machine-based experiments and exploration, it also contains the part called fine arts which, on the outset, was "yielding to the holdingsway and the safekeeping of truth." (1977: 34) And out of this reliance on fine arts, poetry and "everything poetical" included, comes the famous saying, "poetically dwells man upon this earth." (ibid.)

Applying Heidegger's thinking of technology to the analysis of Atwood's novel The Year of the Flood, we can find that, the Compound elites are so delivered over to technology that they have turned everything into standingreserve and therefore, in objectifying humans and exploiting nature ruthlessly, they have failed to see the possible consequences of their domination over everything else. By contrast, the Gardeners, living off the center of the world which is imbued with cutting-edge technological products, know where they 
belong, and come to terms with nature in a primitive way. Astonishingly dramatic and hermit-like as this group seems, their ecocritical beliefs offer an alternative choice in the effort to save the world from being destroyed by the rampant commercialization of technology.

\section{Standing-reserve in the Technological World}

In "Historiography of Biomedicine: 'Bio', 'Medicine', and In Between”, Löwy notes that the increasing reliance of medicine on technologies, instruments, and drugs make the demarcation between "medicine", "science", and "industry" more difficult (2011: 116). Undeniably, with the development of science, people start to make some cross-disciplinary research, which seems like an advanced move. However, this kind of research, resembling an overlapping of various fields and the application of state-of-the-art technology, is blurring the boundary between normal medicines and biomedicines. With ambiguous intentions, biomedicines generate numerous legal loopholes and ignore ethical considerations in spite of the great fortune it brings.

In The Year of the Flood, Health Wyzer is a large medical company that sells health supplements, which Toby's mother used to run a franchise of it. After Toby's father's refusal of selling their family land to the CorpSeCorps, a corporation-controlled security firm, mishap befalls them one by one. At first Toby's father loses his job, and then her mother comes down with a strange illness and eventually she dies in misery. At that time, young Toby could not figure out the reason for her mother's death. Not until she joins the God's Gardeners, and meets Pilar, one of the Eves in this eco-religious group who sheds the light of truth to her, does she begin to realize what has happened to her mother. According to Pilar, Toby's mother has been used as a guinea pig for the HealthWyzer Company. That is to say, her mother has been taking one of the experimental medicines that are still in the testing period. The alleged "customized supplements" are dangerous, for no one knows whether the side effects are strong enough to kill. Having heard Toby's story, Pillar tells her:

Now, promise me that you will never take any pill made by a Corporation. Never buy such a pill, and never accept any such pill if offered, no matter what they say. They'll produce data and scientists; they'll produce doctors - worthless, they've all been bought. (Atwood 2009: 139)

Pilar obviously knows better, since she used to work as a Botanic Splices expert at HelthWyzer. As an insider, her experience with the Corporation enables her 
WU, ZHOU

to know the tricks and dark sides of the experiments. For her, the market-driven corporation run by the wealthy elites has stamped on the ethical considerations and as a result, has turned those biomedicines into lethal killers.

As Pilar unequivocally informs Toby, HealthWyzer is not alone in the making of "the food of the dead," scientists and doctors have joined the corporation in the production of a seemingly persuasive data to promote patients' reliance on those products. To maximize profit, they have pushed aside the "old medical ethic" (ibid.) that puts saving life in the priority and have turned modern technology into what Heidegger calls "challenging revealing," aiming to bring forth more knowledge about the particular kind of medicine they have developed. In the pursuit of desired knowledge, they have dehumanized individuals like Toby's mother and treated them as "lab animals," as free medical resources, and turned them into standing-reserve. In their minds, "all things are being swept together into a vast network in which their only meaning lies in their being available to serve some end that will itself also be directed toward getting everything under control." (Lovitt 1977: xxix) For them, patients are nothing but tools that serve the purpose of scientific experiments.

Without knowing it, consumers have been trapped in this network of standing-reserve. They fail to recognize that they have been objectified and victimized as paving stones for the magnificent building called modern technology. As a faithful user of HealthWyzer's products, Toby's mother increases her dose of HealthWyzer Hi-Potency Vitalvite supplements after she gets sick. Not surprisingly, the more she takes, the weaker she becomes. The whole body seems to turn against itself. As her visits to the Corp clinics increases, she has been given more tests and prescribed more medicines. Trusting the doctors and accepting the treatment, she is unaware that she has become the target of observing, recording and dominating. As one of the Adams - a former Compounder Zeb tells Toby, her mother's physical deterioration is directly related to HelthWyzer scientists who have been "seeding folks with illnesses via those souped-up supplement pills of theirs using them as free lab animals, then collecting on the treatments for those very same illnesses." (Atwood 2009: 326) Based on the data they get from the medical victims, these scientists revise their formulation and update their products. To gain more knowledge, and discover the hidden power beneath the veiled medical reality, they have simply taken human life as "standing-reserve," a resource available to be used and disposed carelessly.

However, consumers are only part of this network. The Compound elites, mostly top scientists, doctors and businessmen, are also caught in this web 
of modern technology. Like the machines and apparatus they employ, or the patients they watch over, they themselves also belong "as stockpart, available resource, or executer, within Enframing” (Heidegger 1977: 29). Simply put, they are also tools and parts of the big machine. Ren's father Frank, one of the top scientists in the Compound, used to be an executer devoted to the development of formulas that would stick "a slow-acting but incurable genespliced disease germ" (Atwood 2009: 389) inside the supplements, causing the death of pill users like Toby's mother. But after his being kidnapped by a rival company, the Compound simply gives him up, based on "a cost-benefit analysis" which concludes that "the disease germs and formulas were worth more to them than Frank was." (Atwood 2009: 390) Undeniably, Frank is treated the same way as the sufferers of his experiment, and as those nameless victims whose vital organs have been harvested and whose gutted carcasses have been found in the meat grinders of local burger stores called SecretBurgers. The only difference is that he is regarded as an intellectual resource, and the other people are merely used physically.

As a result of unregulated biotechnological experiments, genetically modified animals have been brought out, like a liobam which is a lion-sheep splice with the "good" intention of making peace between lions and lambs, a rakunk that is half skunk and half raccoon, and the hybrid bee which is essentially a bee cyborg spy controlled by CorpSeCorps operators. The most horrifying invention is a new human species known as Crakers, named after a scientific prodigy Glenn whose codename is Crake. These people are naked and totally waxed and they have been designed to have extraordinarily strong sexual drives, shown by women's "bimplants" - augmented breasts and men's huge "bright-blue penises." (Atwood 2009: 545) Meeting them in the forest clearing, Ren finds that she has become the sexual target of some Craker men who look more like animals on instinct than men of any moral sense. These people, in her eyes, are "too good-looking - way too perfect" (Atwood 2009: 542 ), but it seems that nobody wants to accept them or get close to them. Apparently, Glenn's megalomania does not bring out a better world. The problem with him, then, is not what he can do with science or technology, but how he deploys human agency in the use of his talent.

Reflective of unlimited human fancies, these bioengineered inventions shed some light into what Adam One calls "the error of pride by considering ourselves as exceptional" (Atwood 2009: 70), and reflects the dark power of manipulative technology. After the satisfaction of human curiosity and fulfillment of technological achievement, what are the creators of these new species going to do with them? Where would they situate them in this world? Without doubt, these 
WU, ZHOU

questions elude the thinking of those scientific geniuses like Glenn. Instead of considering the consequences of their actions, they are more interested in the technical side and are more willing to devote themselves to unlocking the secrets of nature. Unless these executors of technology start to ponder the reality, and try to get to know the truth about the world, their whimsical experiments would not stop, and there will be more victimized standing-reserve.

Disappointed with this technological world imbued with unconstrained desire for profits and unchecked will to control, some top scientists have fled from the Compound, for they cannot bear to see the way nature has been ruthlessly challenged and morality has been mercilessly stamped. Following Adam One, they respect the natural order of the world as it used to be and establish a close community where they help each other in their own way. Restrained by available resources, and probably intentionally keeping themselves away from the Compound system, they turn to nature for sources of inspiration. In the novel, there is an example about how they abandon the Compound style of medical treatment and try natural therapy. When Adam Seven (Zeb) is badly injured in a pleebland street-fight, Pilar takes out her supply of maggots to deal with the decaying flesh. The maggot therapy works well because maggots are capable of killing necrotic bacteria, and patients will recover sooner without the "aid" of Compound medicines that might be potentially harmful. This traditional and helpful method is an effective alternative to the dosages or pills from HelthWyzer.

It is undeniable that sticking to the natural therapy will not work all the time. It is only one of the few choices in that particular situation. When former gene experts Pilar and Katuro fled from the Compound, what they left behind is the way to use technology, not technology itself. As Heidegger indicates, we cannot allow ourselves to be confined "to a stultified compulsion to push on blindly with technology or, what comes to the same thing, to rebel helplessly against it and curse it as the work of devil." (1977: 25-26) Technology is part of our life. It is almost unimaginable to live without technology. On more than one occasion, Heidegger emphasizes the impossibility of giving up on technology, and straightforwardly says that "It would be foolish to attack technology blindly. It would be shortsighted to condemn it as the work of the devil. We depend on technical devices; they even challenge us to ever greater advances.” (1966: 53) Indeed, modern life has been so permeated by technological products that a return to the Stone Age life is more like an illusion than a reality. Given the choice of better and healthier medical facilities, the Gardeners would surely use them for their own good. As a matter of fact, the Gardeners have saved biotechnological formulae and long lines of codes for 
future use, and they maintain a good communication with the other Gardener Rooftop sites through technological methods.

As a mode of revealing, technology is not just about practical use, it also offers a chance for humans to "participate in the way technology manifests" (Tabachnick 2007: 491), and thereby getting to know the essence of technology. As Dreyfus \& Spinosa have suggested, "we can keep our technological devices and yet remain true to ourselves as world disclosers, as receivers of understanding of being" (2003: 342) To rid ourselves of the illusion that technology is completely under our control, and to lift us out of the "frenziedness of technology" (Heidegger 1977: 35), we need to turn to meditative thinking which helps to cultivate our awareness as "world disclosers," to find the true and the beautiful in this world.

\section{Adam One and Poetic Revelation}

As shown in this novel, poetic revelation has been overshadowed by the more eye-catching technological representation of the world. In this aspect, school education is a good case in point. Within the Compound world, the discrimination against humanities is clear. For the students who score high in disciplines like math or science, they can go to Watson-Crick, a college full of brainiacs who would grow to be top researchers in the Compound. If students show no potential in math or science, they would have to be sent to Martha Graham, a school on the verge of collapse, where the buildings are falling apart, the walls are mouldy and the ceilings leak. The regulation sends a clear message to the Compound residents, that is, science is the measurement of an individual's achievement, and arts and poetry are not valued. Compared with biotechnology, arts are obviously disadvantaged in "the hierarchy of erudition and sciences" (Foucault 2003: 8). But different from technical expertise that excavates more tangible truth about the world, arts open up the imagination, point to a further picture about the future, and fire a warning shot about the real danger lurking in modern technology.

What is practiced in the Compound is exactly what Heidegger criticizes in his essay The Question Concerning Technology. As he points out, the current definition of technology, which sees it only as "a means and a human activity," is "instrumental and anthropological." (1977: 5) When the instrumental side is overemphasized, human manipulation of technology would become overwhelmingly dominant. To satisfy the increasing desire to know, and to master, a scientist might be committed to bringing the instrumentality of technology to its fullest extent. But in doing so, he "distanced himself from 
Being, which was manifesting itself in the presencing of all particular beings. For in his seeking, he reached out not simply to receive with openness, but also to control." (Lovitt 1977: xxv) When the obsession with the technological force makes modern man forget who he is, and puts himself in a superior position, there will emerge "a warlike clash between forces" (Foucault 2003: 16). When more biotechnological geniuses like Glenn are "given free reign to tamper with nature" (Bouson 2011: 10-11), what awaits the world is the nightmarish scenario that Atwood speculates in The Year of Flood, the doomsday when humans are wiped off the Earth by the viruses "that cannot be controlled and that are universally destructive." (Foucault 2003: 254)

The instrumental definition of technology, as discussed earlier, is only one layer of meaning. There is still another layer that remains ignored and undervalued, the poetic side which is manifested in "all the fine arts, in poetry, and in everything poetical that obtained poiēsis as its proper name." (Heidegger 1977: 34). Throughout the novel The Year of Flood, arts constitute the daily life of the Gardeners and create for Toby and Ren "a consistent openness that enables everything to appear crisply as a possibility for efficient action." (Dreyfus \& Spinosa 2003: 347) Probably because of their living experience with the Gardeners, these two survivors can face themselves in loneliness and encounter their authentic beings.

For the Gardeners, music occupies a central position in their daily life, offered mostly in the form of hymns. In the entire book, there are more than a dozen poems taken from The God's Gardeners Oral Hymnbook, which are "the primary vehicle for the synthesis of the religious, scientific, and ethical aspects of their belief system." (Hoogheem 2012: 64) Of these poems, some advocate the importance of maintaining ecological balance, which is actually their guiding life philosophy.

The inner bark of Spruce and Birch

For extra Vitamins C -

But do not take too much of each,

Or you will kill the tree. (Atwood 2009: 170)

Some teach people to be grateful for humble creatures, without which "The Earth would be a desert." (Atwood 2009: 216)

We praise the tiny perfect Moles

That garden underground;

The Ant, the Worm, the Nematode,

Wherever they are found. (Atwood 2009: 216) 
Essence of Technology and Ecological Disaster

And there are others that indict human foolishness which brings vanity and pain to modern life.

Oh Lord, You know our foolishness,

And all our silly deeds;

You watch us scamper here and there,

Pursuing useless greeds. (Atwood 2009: 265)

Aside from the hymn poems, there are other chances when music is woven into the daily life. When Toby is sent away to see Pilar who is dying, Nuala offers to fill her class. In her teaching, she explains: "Toby has been called away on an errand of mercy, so let's help her by singing the Weeping Willow song." (Atwood 2009: 236)

Weeping willow, weeping willow, branches

waving like the sea,

While I'm lying on my pillow, come and take

my pain from me... (Atwood 2009: 236; italics in original.)

Here, Nuala rewrites the lyrics and changes the song in a fun way. Instead of having the White Willow which kills the pain, she improvises and turns it into the Weeping Willow, lamenting the impending death of Pilar and at the same time, imparting the knowledge to the Gardeners children in an impressive way. Apart from poems and songs, "painting, sculpture, and handicrafts are all encouraged and even integrated into their liturgical calendar" (Hoogheem 2012: 63-64). These artistic representations, together with Adam One's sermons, help to build a stronger sense of cohesion within the group members and provide a chance for them to ponder social reality and threatening circumstance.

Giving sermons offers Adam One a good chance to organize his ideas and share his thoughts with the other Gardeners. As a former Compound top scientist, he has a clear understanding of what technology can do for humans, both in a positive and negative sense. Unlike those technological conquerors, he holds a pious attitude towards the living beings in this world, believing that all forms of life - human, animal, and plant - have been created by God and are therefore sacred. This view is in sharp contrast with the instrumental conception of technology which "puts to nature the unreasonable demand that it supply energy that can be extracted and stored as such." (Heidegger 1977: 14) According to Adam One, modern man, driven by the insatiable desire to get more from nature, has broken the fellowship with creation because of 
their "murder, lust, and greed." (Atwood 2009: 17) Therefore, it is of vital significance and urgency to show "loving care for all other Creatures." (Atwood 2009: 414) On April Fish Day, he reminds his audience of the threat to sea creatures, arising from global warming which actually results from irresponsible human behavior:

We pray that none may vanish from the Earth by Human agency. Let love and aid be brought to the Sea Creatures and their present peril and great suffering, which has come to them through the warming of the Sea, and through the dragging of nets, and hooks along the bottom of it, and through the slaughtering of all within it, from the Creatures of the shallows, to the Creatures of the depths, the Giant Squid included; and remember your Whales, that You created on the fifth day, and set in the Sea to play therein; and bring help especially to the Sharks, that misunderstood and much persecuted breed. (Atwood 2009: 263)

With the increasing power of technology, humans are able to fish almost everywhere, be it shallow shores or deep oceans. But when fishing becomes slaughtering, more species are dying out, and the holistic ecological system is consequently threatened or damaged. Outraged by human foolishness, Adam One seems to sense the suffering of sea creatures and feels their pain. In celebrating Saint Dian's Day, he highlights the importance of interspecies empathy by narrating how Saint Dian Fossey fought for the Gorillas which had been ruthlessly exploited and how she gave up her life in the pursuit of "a Peaceable Kingdom in which all Life would be respected.” (Atwood 2009: 414) In meditating upon Saint Euell Gibbons, he reinforces the close tie between humans and nature. As a man rich in natural knowledge, Adam One preaches, Saint Gibbons "knew the roadside medicines: the bark of the Willow in respect of pains and fevers, the root of the Dandelion as a diuretic in the shedding of excess fluid. He taught us not to waste; for even the lowly Nettle, so often wrenched up and thrown away, is a source of many vitamins." (Atwood 2009: 168) To live within nature rather than over nature, Adam One has pointed out a direction for his followers, a possibility to build a biosphere-friendly environment in the future.

Environmental concerns are commonly found in Adam One's sermons. From the sea to the land, he directs the followers' and also the readers' attention to the marred traces left by the speedy chariot of modern technology: "Consider the southern shores of the Mediterranean - once fruitful farmland, now a desert. Consider the ruinations wrought in the Amazon River basin; consider the wholesale slaughter of ecosystems, each one a living reflection of God's infinite care for detail..." (Atwood 2009: 119) As the depressing picture shows here, a huge price has been paid and "fruitful farmland" has become 
Essence of Technology and Ecological Disaster

"a desert" and the ecosystem has been severely endangered. In the pursuit of greedy gains, technology has been endowed with an unconquerable force and the false impression that technology is under complete control helps to boost human confidence in their exploitation of natural resources.

Greatly concerned with human violence and the suffering of other living creatures on the Earth, Adam One raises questions about human nature, "What is it about our own Species that leaves us so vulnerable to the impulse to violence? Why are we so addicted to the shedding of blood? Whenever we are tempted to be puffed up, and to see ourselves as superior to all other Animals, we should reflect on our own brutal history." (Atwood 2009: 414415) Worried that those "scientific fools" take nature as "standing-reserve" and, in their blind arrogance, exalt themselves "to the posture of lord of the earth" (Heidegger 1977: 27), he frequently warns about the possibility of the outbreak of an unavoidable ecological disaster which is called Waterless Flood: "it travelled through the air as if on wings, it burned through cities like fire, spreading germ-ridden mobs, terror, and butchery." (Atwood 2009: 25) As the plot unfolds, a massive die-off of the human race happens and the majority of the population disappears. But for the Gardeners, the ability to imagine the future and foresee the disaster, prepares them for the impending catastrophe as well as the post-disaster life.

Examining the relationship between humans and nature constitutes one of the important parts in the Gardeners' life. As Adam One says, "Science is merely one way of describing the world. Another way of describing it would be to say: where would any of us be without Love?" (Atwood 2009: 476) The effort to "meld spirituality and science" (Deresiewicz 2009: 28), is distinctively revealed in Adam One's sermons. Trained as scientists, Adam One and the other Adams in this eco-religious group surely know it is irrational and noncommonsensical to give up the scientific basis in their explanation about the world. But what they endeavor to do is to plant the seed of love in human hearts- the love for the living beings in the world. In his sermon entitled "Of the foolishness within all Religions," Adam One capitalizes on the celebration of April Fish Day to elaborate on the relationship between generations:

Our children always enjoy this day, as it allows them to make fun of their elders; and as long as that fun does not get out of hand, we elders welcome it, as it reminds us of our own childhoods. It never hurts to remember how small we felt then, and how we depended on the strength, knowledge, and wisdom of our elders to keep us safe. Let us teach our children tolerance, and loving-kindness, and correct boundaries, as well as joyful laughter. (Atwood 2009: 261) 
WU, ZHOU

These teachings are hard to get inside the Compound where fathers spend most of the time doing the experiment. Different from her Rooftop Garden experience where she meets the adults every day, exposes herself to their influence, and observes how they interact with each other and with the world around them, Ren scarcely sees her father around, either before her arrival at the Garden or after her return to the Compound. Likewise, Jimmy's father seems like a stranger to him, for he is always at the lab, "figuring out how to transplant human stem cells and DNA into pigs, to grow new human pieces" (Atwood 2009: 294) which would be used to replace human kidneys or lungs.

As a Heideggerian meditative person, Adam One has illustrated the practice of "arts of the mind" by his words and his deeds, exemplifying the dimension of poetic revealing in an emblematic way. To have meditative thinking, as Heidegger explains, is within the capability of all humans so long as "we dwell on what lies close and meditate on what is closest; upon that which concerns us, each one of us, here and now; here, on this patch of home ground; now, in the present hour of history." (1966: 47) Living in the age of technological revolution which "could so captivate, bewitch, dazzle, and beguile man" (Heidegger 1966: 56), Adam One chooses to look beyond and explore what is beneath technology and contemplate the meaning of life. His sermons come from his constant reflection upon their situation, and his endless effort to make sense of the world around him, therefore, they are instructive and exemplary, laying the foundation for the belief system of the Gardeners.

Led by Adam One, and supported by the other Adams and Eves, God's Gardeners group has prospered on this "sizzling wasteland, hemmed in by festering city slums and dens of wickedness" (Atwood 2009: 13), and its growing influence has attracted more followers. Following their pattern, "[m] any rooftops were blossoming as the rose, many hearts and minds were bent towards an Earth restored to balance." (Atwood 2009: 365) In spite of their efforts to "put something back into what is proper and right, into the essential, and to keep it safe therein" (Heidegger1977: 41), they fail to reverse the trajectory or change the society in a significant way. That is, their resistance against the technological world is too weak to "ward off the larger environmental collapse.” (Bergthaller 2010: 738) Not long after Toby leaves the Garden, and settles down in a spa as a manager, she gets news about the "strange outbreaks of new diseases, or peculiar infestations" (Atwood 2009: 361). When the local outbreak of the epidemic cannot be contained, it becomes an emergency throughout big cities around the world - "it was like watching the planet being spray-gunned.” (Atwood 2009: 375) Finally, the seed of 
destruction developed in bio-labs is hitting back onto human beings, including the technological executors themselves.

After going through the ordeals, Toby, Ren and two former Gardener children Amanda and Jimmy eventually get together for a new start in the ruined world. This arrangement is indicative of Atwood's hope for the world. In particular, the music part in the last paragraph strikes a promising note to the whole book. After Jimmy keeps murmuring, "You can't kill the music," Toby and all the survivors hear something which is "faint and far away, but moving closer. It's the sound of many people singing. Now we can see the flicking of their torches, winding towards us through the darkness of the trees." (Atwood 2009: 572) Indeed, the physical wealth built on technological advancement might be destroyed, but arts like music would remain. Symbolic as the ending looks, this story provides us a solution to the potential crisis arising from the technological arrogance, and sets us thinking about the essence of technology.

\author{
Wu Lanxiang \\ wulanxiangjoy@126.com \\ Southeast University \\ Nanjing 211189 \\ P. R. CHINA
}

\title{
Zhou Xiaolin
}

kitty523cd@163.com

Southeast University

Nanjing 211189

P. R. CHINA

\section{Bibliography}

Atwood, M. 2009. The Year of the Flood. New York: Anchor Books.

Bergthaller, H. 2010. Housebreaking the Human Animal: Humanism and the Problem of Sustainability in Margaret Atwood's Oryx and Crake and The Year of the Flood. English Studies, 91(7), 728-743.

Bouson, J. B. 2011. "We're Using Up the Earth. It's Almost Gone”: A Return to the Post-Apocalyptic Future in Margaret Atwood's The Year of the Flood. - Journal of Commonwealth Literature, 46 (1), 9-26.

Canavan, G. 2012. Hope, But Not for Us: Ecological Science Fiction and the End of the World in Margaret Atwood's Oryx and Crake and The Year of the Flood. - LIT: Literature Interpretation Theory, 23(2), 138-159.

Deresiewicz, W. 2009. Honey and Salt. - The Nation, November 2, 25-32. 
WU, ZHOU

Dreyfus, H. L.; Spinosa C. 2003. Further Reflections on Heidegger, Technology, and the Everyday. - Bulletin of Science, Technology \& Society, 23 (5), 339-349.

Foucault, M. 2003. Society Must Be Defended: Lectures at the College de France, 19751976. Transl. by D. Macey. New York: Picardo.

Heidegger, M. 1966. Discourse on Thinking. Transl. by J. M. Anderson and E. H. Freund. New York: Harper \& Row.

Heidegger, M. 1977. The Question Concerning Technology and Other Essays. Transl. by W. Lovitt. New York \& London: Harper \& Row.

Hoogheem, A. 2012. Secular Apocalypses: Darwinian Criticism and Atwoodian Floods. - Mosaic, 45 (2), 55-71.

Lovitt, W. 1977. Introduction. - M. Heidegger, The Question Concerning Technology and Other Essays. Transl. by W. Lovitt. New York \& London: Harper \& Row, xiiixxxix.

Löwy, I. 2011. Historiography of Biomedicne: "Bio," "Medicine," and In Between. Isis, 102 (1),116-122.

Oates, J. C. 2006. Margaret Atwood's Tale. - New York Review of Books 53(17), 1822. http://www.nybooks.com/articles/2006/11/02/margaret-atwoods-tale (06.03.2019).

Tabachnick, D. E. 2007. Heidegger's Essentialist Responses to the Challenge of Technology. - Canadian Journal of Political Science, 40 (2), 287-505. 